\title{
Time Structure Optimization of Logistics Chain during Assembly
}

\author{
Miriam Pekarčíková ${ }^{1, *}$, Peter Trebuňa ${ }^{1}$, Jaromír Markovič² \\ ${ }^{1}$ Department of Industrial Engineering and management, Technical University of Košice, Faculty of Mechanical Engineering, Košice, Slovakia \\ ${ }^{2}$ Slovak legal metrology, Banská Bystrica, Slovakia \\ *Corresponding author: peter.trebuna@tuke.sk
}

Received October 07, 2014; Revised October 21, 2014; Accepted November 06, 2014

\begin{abstract}
There are many reasons that point to the need to deal with optimization of production processes. This article deals with improving the efficiency of the assembly process through optimization of its time structure. It is a necessary tool for ensuring growth of the organization, whether in professional or economically. The company can thus achieve a higher level of significance not only in the domestic but also foreign markets.
\end{abstract}

Keywords: optimization, costs, logistics, assembly

Cite This Article: Miriam Pekarčíková, Peter Trebuňa, and Jaromír Markovič, "Time Structure Optimization of Logistics Chain during Assembly.” American Journal of Mechanical Engineering, vol. 2, no. 7 (2014): 262264. doi: 10.12691/ajme-2-7-18.

\section{Introduction}

Effort to maintain the company's competitiveness and ensuring a strong position in the market creates a need of analyze the impact and consequences of individual processes to optimize the overall performance of the enterprise. Such thinking was applied to a specific product mix of the company involved in the production of electrical products. Priority in solving the optimization problem was to achieve growth of profitability indicators and shortening of assembly time.

\section{Time Structure of Assembly}

Assembly operations as a basic unit crucially affect the productivity and overall efficiency of the entire production and assembly process. To increase the productivity of the entire production-assembly process is necessary to analyze the individual steps of assembly cycle, eventually find a solution that would be optimal and was used the gradual, concurrent or combined form of production-assembly process.

The first level creates a conceptual model implementing the assembly process. Indicates the principle of assembly solutions and determines the sequence of the productionassembly phases. It is therefore appropriate at this phase to create several structures (sub-assemblies) in order to clear the sequence and continuity of assembly steps. Assembly of guard portion is characterized by concurrent form of assembly process. Parts and assemblies going from department $P_{n}$ to department $P_{n+1}$, and the total time of protector assembly cycle takes about $5.4 \mathrm{~min} /$ unit (one worker).
Figure 1 shows that assembly E19376 is composed of the assembly of sub-assemblies E19377 and D6908. The time required for mounting the sub-assemblies in the first case is $1.19 \mathrm{~min}$. and for D6908 $1.43 \mathrm{~min}$. The observed difference is the value of $0.23 \mathrm{~min}$., representing 13.8 seconds (which corresponds to a given professional estimate according to the technological process).

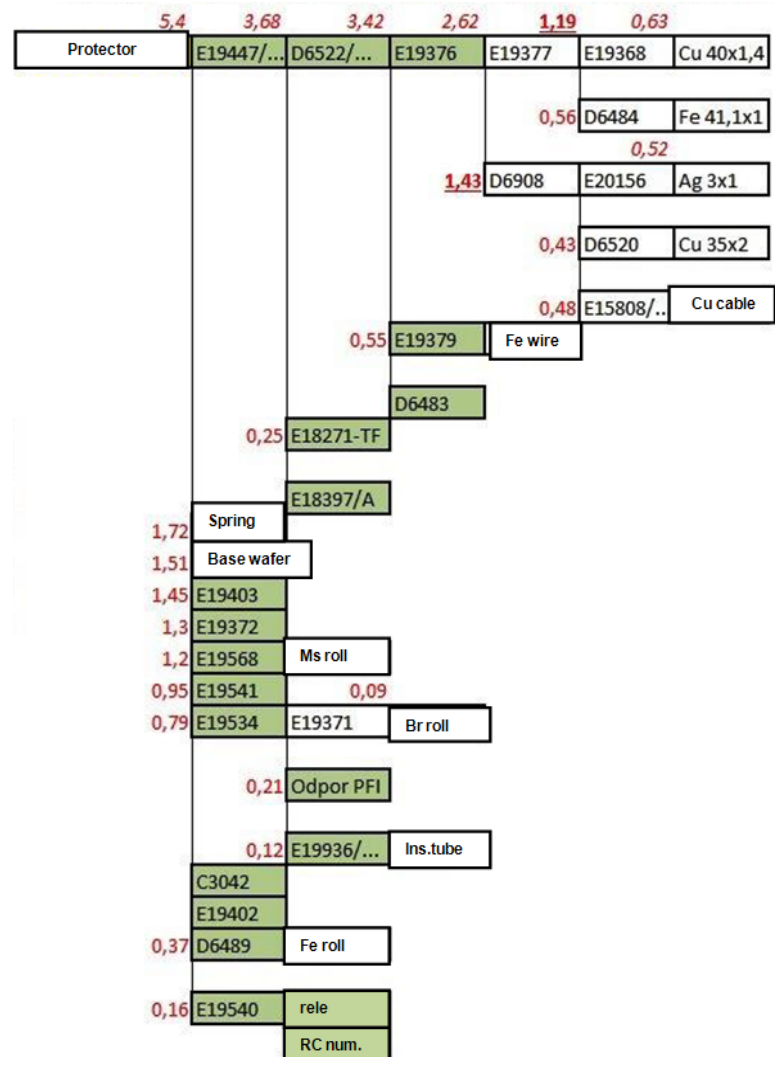

Figure 1. Installation of protector and times 
To increase the efficiency of the process is necessary to eliminate this inconsistency, respectively at least minimizing it. For the analysis of the assembly, but also the production is suitable production-assembly scheme, which determines when and in what order entering different materials, semi-finished products and assemblies to the assembly at level higher units.

Figure 1 shows that the assembly of D6908 takes 1.43 min. It is necessary to take into account sub-assemblies, which will be the main object of solving the problem:

• E20153 (0.52 min.)

- D6520 (0.43 min.)

- E15808 / ... (0.48 min.).

The assembly process of protector can be determined from Figure 2, there is illustrated a diagram of overlap by assembly of protector MFI II., specifically in the field of D6522, on which will be realized optimization. Diagram of overlap shows which sections can or should be optimized.

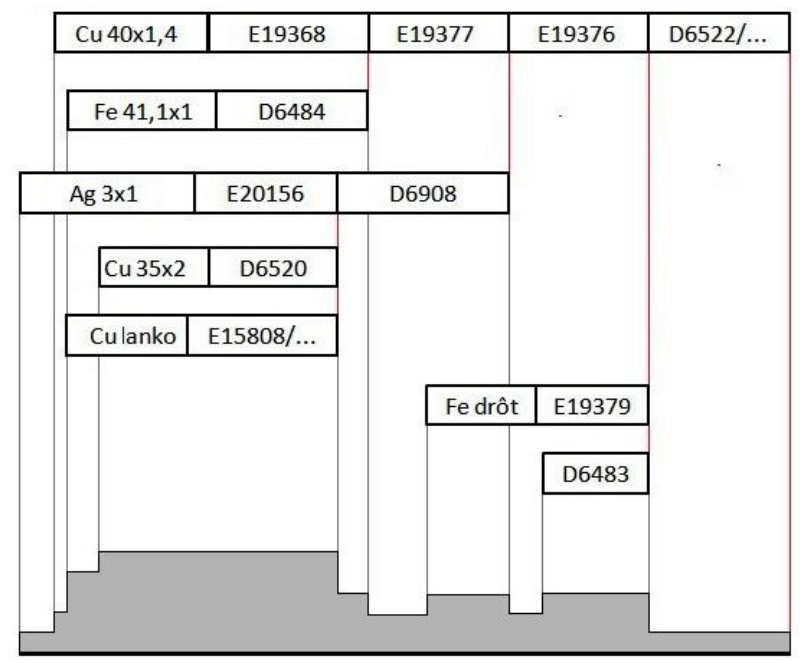

Figure 2. Diagram of overlap of assembly processes -the initial state

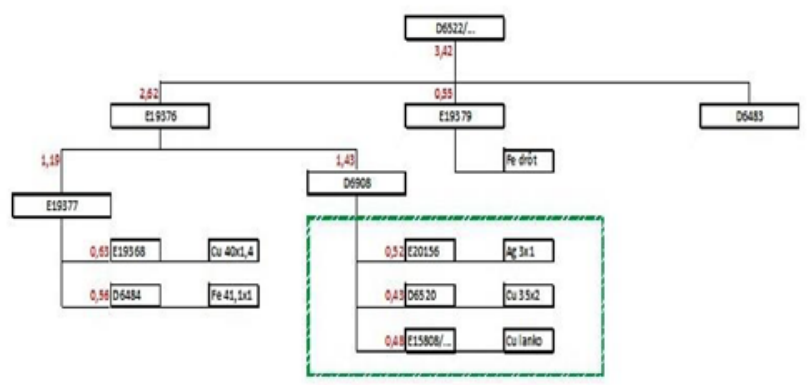

Figure 3. Field of solutions

Figure 3 shows the production-assembly diagram of the D6522, even with the parts in which it is possible to design a solution that will be suitable and optimal. As already known, assembly at this level is a parallel and in line and carried out on separate work units ( 1 worker $=1$ level). Figure 3 also shows part of the proposal of solution, this part is displayed in green frame.

The proposal consists of solutions that will shorten assembly times the area of E19376. In the D6908 is the longest operation of the E20156 (0.52 min.). Using dabbler ( 2 workers at that level) shortened assembly time in half (i.e., $0.26 \mathrm{~min}$.). The proposed solution is schematically shown in Figure 4.

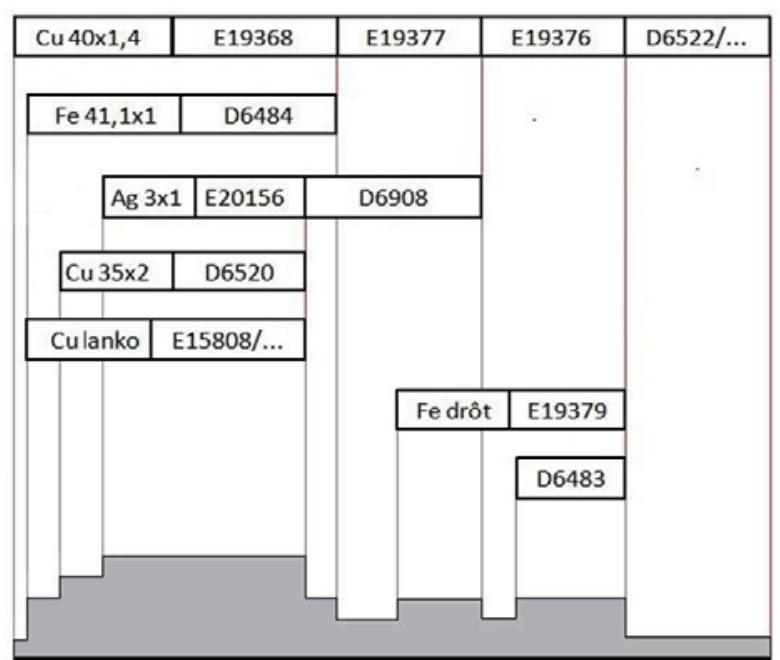

Figure 4. Chronogram of solution

Assembly of this part will be:

$$
\begin{aligned}
& \text { TD6908 = TE20156 + TD } 6520+T E 15808 / \ldots \\
& =0,48+0,43+0,26=1,17 \mathrm{~min} .
\end{aligned}
$$

From equation (1) shows that the assembly time on the level D6908 decreased to $1.17 \mathrm{~min} /$ piece. The longest continuous installation operation will constitute E15808. Then the characteristics of the proposed assembly process will be as follows:

The longest operation on the 4th level D6522 / ...

$T M A X=3,42+2,62+1,43+0,48=7,95$ min.

The sum of duration of assembly operations at the 4th level of assembly:

$$
T^{\prime}=\Sigma T i=7,86+7,79+7,99+7,9+7,95=39,49 \min \text {. (3) }
$$

Continuous concurrency of assembly processes:

$$
\alpha=T^{\prime} / T M A X=39,49 / 7,95=4,967
$$

Production and assembly diagram after applying the proposed solutions will be displayed as follows according to Figure 5.

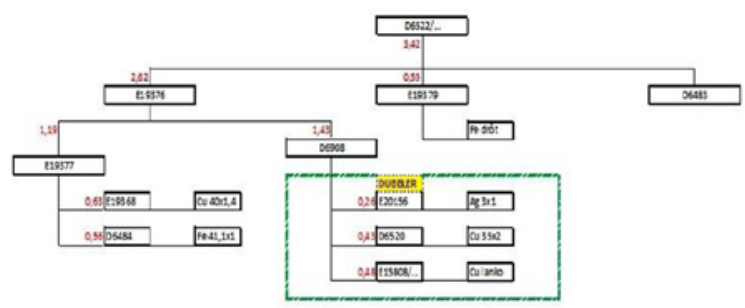

Figure 5. Proposal for assembly scheme

In the selection of assembly part in which would be possible to optimize was reflected mainly the temporal factor, while the gain of staffing has been applied for the longest assembly operations at the seventh level assembly. With secure of access materials and information was able to realize the optimization of the specific part of the assembly process, i.e. shorten assembly times through the movement of labour in resp. change in the manufacturing and assembly process. In this model is necessary a careful analysis of the use of labour and the subsequent reorganization of the assembly process to work activities were utilized efficiently and focus on the optimal 
sequence of assembly operations. By shortening the assembly time can be achieved increasing of productivity, thus the volume of production during the unit time increases. This is an incentive for sales growth and increase the amount of goods offered in the market. There is no need to increase the number of employees due to the fact that individual workers as necessary move to departments. Wages and salaries to employees so remain constant and productivity is increased. Higher productivity mediates several advantages such as increasing the number of products, higher turnover, greater coverage of the market, meet a larger number of customers, flexible response to orders from customers and so on.

\section{Conclusion}

Proposal resolution of the case study was based on a study of a particular sub-assembly, assembly time analysis of individual elements in detachable units and the optimal allocation of assembly technologies, taking into account the quantity and the use of labor in order to streamline manual operations. The different stages of the production process, it is necessary to break down into subgroups to monitor bottlenecks in production, to apply the results of science and research with an emphasis on the application of new advanced technology. Monitor the impact of the proposed solutions to the production cycle, to analyze the overall benefits and to take measures to achieve the optimal solution given the competitive position of the company.

\section{Acknowledgement}

This article was created by implementation of the grant project KEGA 4/2013 Intensification of modeling in education of II. and III. degree in the field of study 05/02/52 Industrial Engineering.

\section{References}

[1] ALÁČ, P.: Modely rozhodovania v logistickom ret'azci. In: MVK Logisticko-distribučné systémy. Zborník referátov. TU Zvolen, 2007.

[2] FRYC, E.: Optimalizácia výroby elektrotechnického výrobku v spoločnosti SEZ Krompachy a.s., Bakalárska práca, SjF TU Košice, 2013

[3] KOVÁČ,J. - SVOBODA,M. - LÍŠKA,O.: Automatizovaná a pružná montáž. Vydanie1. Košice: Vienala,2000. 200 s.

[4] MALINDŽÁK, D., et al.: Aplikácia modelovania a simulácie v logistike podniku aplikácia modelovania a simulácie, Košice: TU, FBERG - 2009. - $286 \mathrm{~s}$.

[5] MIHOK,J.: Výroba elektrických strojov. Košice: Edičné stredisko VŠT, 1989. $264 \mathrm{~s}$

[6] ROSOVÁ, A.: Podniková logistika, 1. vyd. - Košice : TU - 2012. 100 s.. - ISBN 978-80-553-0881-4.SAKÁL, P. - JERZ, V.: Operačná analýza v praxi manažéra II., SP Synergia, Trnava, 2006.

[7] STRAKA, M.: Distribučná logistika v príkladoch, ES Fa BERG, TU v Košice, 2011.

[8] TREBUŇA P. - FILO, M. - PEKARČÍKOVÁ M.: Zásobovacia a distribučná logistika a príkladoch, Košice 2012.

[9] TREBUŇA P. - PEKARČÍKOVÁ M.: Zásobovacia a distribučná logistika, Košice 2011. 